\title{
Urgences
}

\section{perdre sa peau...}

\section{Louise Beauchamp}

Numéro 13, mars 1986

\section{Éclats d'atelier}

URI : https://id.erudit.org/iderudit/025234ar

DOI : https://doi.org/10.7202/025234ar

Aller au sommaire du numéro

\section{Éditeur(s)}

Urgences

\section{ISSN}

0226-9554 (imprimé)

1927-3924 (numérique)

Découvrir la revue

\section{Citer ce document}

Beauchamp, L. (1986). perdre sa peau... Urgences, (13), 76-77.

https://doi.org/10.7202/025234ar

Ce document est protégé par la loi sur le droit d'auteur. L'utilisation des services d'Érudit (y compris la reproduction) est assujettie à sa politique d'utilisation que vous pouvez consulter en ligne.

https://apropos.erudit.org/fr/usagers/politique-dutilisation/
Cet article est diffusé et préservé par Érudit.

Érudit est un consortium interuniversitaire sans but lucratif composé de l'Université de Montréal, l'Université Laval et l'Université du Québec à Montréal. Il a pour mission la promotion et la valorisation de la recherche. https://www.erudit.org/fr/ 


\section{Louise Beauchamp}

perdre sa peau en haleine courte, dans une projection en tout sens, sur tous les murs, sans queue ni tête, éparse, autour du lit, collée à sa peau froide,

se perdre totalement, se liquéfier à sa couleur cerise fondue en blanc, je rentre dans tous ses pores, je me pénètre et j'éjacule folles idées en ses fondations vieillies, on se bat frénétiquement, en douceur, de ma cage à ses intestins, dans un mariage carnaval de grossièretés délicieuses,

ne pas perdre de vue le tableau suspendu au mur, il existe en ses plus beaux excès, à tout moment je pourrais me retrouver saisie par quelques gênants soubresauts entrecoupés de petites pauses très courtes, à faire perdre haleine, ou me ramasser en l'air quelque part dans le tableau, couchée subitement près d'elle, entre l'île et le corbeau, il me dirait sûrement nevermore à moi aussi, écartée, le sexe ravagé, dans la même faute, les mêmes faux alibis, la même frustrante pudeur, néanmoins fort dérangeante,

perdue, des spasmes de chaleur finissent par m'évanouir à petit feu, dans tous les cris rouges, stridents, de la bête de nuit au regard perçant, noir, jamais plus, non, jamais plus,

totalement perdue, la froidure, la finitude, collée au mur, délicieusement, les cheveux mouillés, gelés, depuis hier sans repos le corps bouillant sans lest, liquide blanchâtre partout sur moi répandu entre les rougeurs inévitables, tableau, abstraction sur fond de peau, sur fond de toile, glissements rugueux, poils et cils hérissés, frottements irritables suscitant tous les regards dans le fond de toutes les chambres du monde,

perdue, délivrée des draps et des bras quelconques, les épines des 
roses rouges crèvent ma peau, formant échardes oscillantes, signe de perfection, mouvement magique des cieux jusqu'à la nuit divine, tentatrice des temps perdus,

perdue, projetée d'un siècle à l'autre, d'un soubresaut à un autre sur un plancher autour du lit, sur quelques aires de basse voix et de mortelie musique exaltante, le chandelier à sept branches chasse les mauvais esprits, des ombres géantes s'agitent sporadiquement sur les murs dans une cacophonie de gémissements animaux, de lyres en délire, de plaintes à n'en plus finir de se tordre, j'ai peur pour ma peau 